\title{
Psychological Capital, Personality Traits of Big-Five, Organizational Citizenship Behavior, and Task Performance: Testing Their Relationships
}

\author{
Udin UDIN ${ }^{1}$, Ahyar YUNIAWAN²
}

Received: July 03, 2020 Revised: July 25, 2020 Accepted: August 10, 2020

\begin{abstract}
This study's primary purpose is to explore the psychological capital roles and personality traits of Big-Five in predicting OCB (organizational citizenship behavior) and performance of task in Indonesia's electricity sector. The data were gathered from the employees of four major cities in Indonesia, in Southeast Sulawesi, comprising 246 employees. The data were analyzed utilizing a PLS (partial least squares) based SEM (structural equation modeling) technique. The findings indicate that the psychological capital and personality traits of Big-Five relate significantly to OCB and the performance of task. Nevertheless, against our expectations, OCB does not significantly relate to the performance of task. This study also discusses the findings' further implications. In terms of practical implications, the findings of this research stipulate that psychological capital and Big-Five personality traits aimed to improve employee performance and can be most effective if specifically targeted at OCB. Given that both variables play an important role to promote OCB, caring training initiatives that focus on mutual help can be very valuable for organizational improvement. In a managerial perspective, organizations can increase OCB by conducting open communication strategies between managers and employees to further stimulate and strengthen the ability of employees to display extra-role behaviors.
\end{abstract}

Keywords: Psychological Capital, Personality Traits, Big-Five, OCB, Performance of Task

JEL Classification Code: D19, D22, D23

\section{Introduction}

Immense technological and economic changes, development in culture, and globalization have impacted the organizational competition's structure and intensity. They have also influenced other sectors in Indonesia and particularly the electricity sector. In the developing economy, the organization should be skilled to retain and encourage greatly talented employees to keep a competitive edge.

Employees are an organization's crucial element since those who start their formation have a vital part in decision-

${ }^{1}$ First Author and Corresponding Author. Lecturer, Business and Economic Faculty, Universitas Muhammadiyah Yogyakarta, Indonesia [Postal Address: Jl. Brawijaya, Tamantirto, Kec. Kasihan, Yogyakarta, 55183, Indonesia] Email: udin_labuan@yahoo.com

${ }^{2}$ Associate Professor, Business and Economic Faculty, Universitas Diponegoro, Semarang, Indonesia

(c) Copyright: The Author(s)

This is an Open Access article distributed under the terms of the Creative Commons Attribution Non-Commercial License (https://creativecommons.org/licenses/by-nc/4.0/) which permits unrestricted non-commercial use, distribution, and reproduction in any medium, provided the original work is properly cited. making and decide the organization's survival (Buchko, Buscher, \& Buchko, 2017). Employees are the power and energy source in the frictions, activities creation, and actions inside the organization. With no participation of the employees, the organization will not be able to increase the effectiveness, productivity, and efficiency in chasing the general goals (Buchko et al., 2017; Kang \& Sung, 2017; Poulsen \& Ipsen, 2017). The employee-level participation inside the organization is highly controlled by the employee's individual characteristics. The diverse employee characteristics would impact her/his behavior in completing the tasks. One characteristic that affected the behavior of each employee is the psychological capital, which could assist the employees to increase performance in the working environment (Karatepe \& Talebzadeh, 2016; Kim et al., 2017; Tüzün, Çetin, \& Basim, 2018).

The employee's psychological capital investment is meant to improve his/her adequate competence to overcome the globalization challenges and develop citizenship of organization that, in turn, is directed to the effectiveness of the organization (Pradhan, Jena, \& Bhattacharya, 2016). Employees who are more positive psychologically would 
perform higher OCB (organizational citizenship behavior) than the employees who are negative. The employees would utilize their minds and actions considerably by choosing time advantage. They would show their ability to perform proactive behaviors, for example by offering suggestions or exchanging creative ideas for increasing employees' work efficiency (Kim et al., 2017; Tüzün et al., 2018).

There are various factors that decide organizational optimal performance, such as personality (Ward, Meade, Allred, Pappalardo, \& Stoughton, 2017). Personality takes a crucial role in deciding each employee's behaviors and habits. Personality differentiations influence how the employee responds to the conditions in their working environment (Harris \& Fleming, 2017; Ward et al., 2017). Employees that have emotionally stable characteristics would be inclined to offer help to another employees in completing their work (Ashkanasy, Troth, Lawrence, \& Jordan, 2017). Moreover, the employees who benefits from their works would complete the tasks better (Harris \& Fleming, 2017). Therefore, by investigating psychological capital of the roles and personality traits of Big-Five in predicting $\mathrm{OCB}$ and performance of task, this study not only extends psychological studies, but also extends the organizational effectiveness particularly in the electricity sector of Indonesia.

\section{Literature Review}

\subsection{OCB (Organizational Citizenship Behavior)}

OCB is performed without restraint by a person. It does not explicitly or directly relate to the organization's incentive structure, but it could improve the effectiveness of the organization (Desivilya, Sabag, \& Ashton, 2006; Rashi \& Konark, 2002; Robbins \& Judge, 2011). OCB is concerned with the action of the employee, which exceeds the roles required by the organization, where that action improves the co-workers' wellbeing, the organization, or the working teams (Organ, 1988; Organ, Podsakoff, \& MacKenzie, 2006).

OCB involves the persistence of the employee in offering to do the task that is not officially given, integrating extra enthusiasm and tasks completion effort, protecting, supporting as well as sustaining goals of the organization, following practices and rules of the organization, and working and assisting each other (Borman \& Motowidlo, 1993). Organ (1988) notes that there are five dimensions in OCB: (1) sportsmanship, concerning the disturbances tolerance attitude in the working environment; (2) courtesy, concerning teaching others action before they make decisions or take steps associated to their work; (3) civic virtue, concerning the action taken to involved in and support the administrative functions in the organization; (4) conscientiousness, concerning the action taken to show a given task that exceeds what is expected by the organization; and (5) altruism, concerning the employee assisting other employees to finish the tasks in particular conditions.

Chien (2003) states that the OCB application in the working environment could develop the performance of the individual employee, performance of the unit, and performance of the organization. OCB influences employee performance because it includes a strong conviction that $\mathrm{OCB}$ is essential to organizational success (Basu, Pradhan, and Tewari 2017; Hermawati and Mas 2017), (Dong \& Phuong, 2018). Empirical results indicate that OCB implants a public service ethic (Rayner, Lawton, \& Williams, 2012), diminishes clashes between the employees (Beheshtifar \& Hesani, 2012), and develops performance of the employee (Asiedu, Sarfo, \& Adjei, 2014; Darsana, 2013; Harwiki, 2013; Maharani, Troena, \& Noermijati, 2013; Putri, Udin, \& Djastuti, 2019; Shahab, Sobari, \& Udin, 2018; Suwanti \& Udin, 2020).

\section{H1: OCB relates positively to the performance of task.}

\subsection{Psychological Capital}

Hmieleski and Carr (2008) refer to the psychological capital as a groundwork comprising of the hope (Snyder, Sympson, \& Ybasco, 1996), self-efficacy elements (Bandura, 1997), optimism (Carver \& Scheier, 2003), and resilience (Masten, 2001). Luthans, Avolio, Avey, and Norman (2007) define 'psychological capital' as a psychological state of mind distinguished by a motivation or positive state to reach success (hope), a positive psychology that could urge a person to go up from breakdown or complete extra tasks (resilience), high self-confidence in countering the challenges (self-efficacy), and high optimism or a positive attribution concerning to present and upcoming success (optimism). Yardley (2012) further explains that psychological capital refers to the positive power that arises from the internal person and increases success in the workplace.

The self-efficacy refers to a person's belief about the individual ability to utilize programs for necessary action, motivation, and cognitive resources to achieve success in accomplishing particular tasks in a specific circumstances (Herbert, 2011). An employee with high self-efficacy is inclined to believe in the current abilities they have to succeed in the given tasks performance (Rego, Marques, Leal, Sousa, $\&$ Cunha, 2010). Herbert (2011) further stated that persons who have high self-efficacy would select and enjoy tasks that are considered challenging, which could show their ability to overcome any difficulties or obstructions to those tasks performance.

Hope refers to a thought or cognitive process in which persons can build reality with challenging or intriguing 
goals and eventually achieve the goals through the determination of self-directed, internal control perception, and energy (Youssef \& Luthans, 2010). Employees with high hope would be encouraged to reach their goals and own determination and energy to accomplish the expectancy (Rego et al., 2010). Further, Youssef and Luthans (2010) add that optimism is a thinking mode whereby persons attribute perpetual positive circumstances to themselves. Meanwhile, Rego et al. (2010) argue that optimism is the persons' hope that something good would occur to them. Optimists would not surrender easily and generally incline to possess an action plan in any problematic situation. Employees with optimistic characteristics would consider setback as a chance or challenge that could eventually direct to success (Luthans, Avolio, Walumbwa, \& Li, 2005). The employees also have a more persistent characteristic in facing obstructions, and show more proficiently in evaluating the external context in a working environment (Youssef \& Luthans, 2010).

Resilience is a capacity positive psychology, which could allow the employee to come up from breakdown and undertake extra tasks. The definition of 'resilience' is a capacity of positive psychology to evade conflict, failure, and uncertainty and to make positive progress, responsibility and change (Luthans \& Jensen, 2002). Employees who have high resilience would possess the ability to face a meaningful life, receive reality and, highly, have the capability to adapt to changes (Coutu, 2002).

To compete effectively in the modern working environment, the organization does not only hire talented employees, but also ought to be able to encourage and support them to utilize every part of the skills they have to the work (Bakker, Albrecht, \& Leiter, 2011). Nelson and Cooper (2007) state that the behavior of positive organization research has reported that employees who have psychological capital could demonstrate the jobs they have successfully.

The investment in the employee's psychological capital is aimed to increase adequate competence for the employee to counter the globalization challenges and develop citizenship of an organization that, in turn, is directed to the effectiveness of the organization (Murthy (2014). Employees who are more positive psychologically would show better OCB than the employees who are psychologically negative. They would utilize their minds and actions significantly by choosing time advantage. They would show their ability to perform proactive behaviors, for example, by creating suggestions or exchanging creative ideas for increasing employees' work efficiency (Avey, Luthans, \& Youssef, 2008).

Furthermore, employees with positive psychological capital would perform work simultaneously to establish a positive, unique life side in the working environment. They also would endeavor to be successful by finishing tasks well (Norman, Avey, Nimnicht, \& Pigeon, 2010). Empirical results reveal that psychological capital decreases stress of employee (Luthans, Avey, \& Jensen, 2009), develops OCB (Avey et al., 2008; Beal, Stavros, \& Cole, 2013; Murthy, 2014), and increases performance of employee (Hodges, 2010; Karatepe \& Talebzadeh, 2016; Kim et al., 2017; Liu, Hu, Wang, Sui, \& Ma, 2013; F. Luthans, Avey, Avolio, \& Peterson, 2010; Nguyen \& Ngo, 2020; Norman et al., 2010; Peterson, Luthans, Avolio, Walumbwa, \& Zhang, 2011; Venkatesh \& Blaskovich, 2012).

H2: Psychological capital positively relates to $O C B$.

H3: Psychological capital positively relates to the performance of task.

\subsection{Personality Traits of Big-Five}

According to Darsana (2013), personality is frequently inferred to an individual's character or attitude viewed in some circumstances. Moreover, Robbins and Judge (2011) claim that personality is the totality of the ways where persons interact with and respond to another. Personality is traits of complex behavior comprising of temperament (emotional response in react to sates or stimuli of the spontaneous environment) and the individual unique emotions, which differentiate a person from another (Han, 2020; Jalal, Zeb, \& Fayyaz, 2019). Cervone and Pervin (2013) mention that, in particular, two factors are responsible to affect personality: environmental and genetic factors. Environmental factors comprise family, social class, culture, situations, and peers, while genetic factors are concerned with the individual unique aspects.

Najari, Ahmadi, and Habibitabar (2011) declare that, in the model of BigFive, personality is assessed by several dimensions that differentiate individuals from each other, consisting of conscientiousness, openness to experience, neuroticism, extroversion, and agreeableness. Conscientiousness concerns the goals that interests a person's attention. People with a high scoring is inclined to listen to pursue consciously several goals purposefully. $\mathrm{He} / \mathrm{she}$ is, hence, highly dependent, achievement-oriented and defensive. Openness to experience happens when an individual is attracted by innovation and novelty and is inclined to be intellectual, imaginative, and sensitive. He/she appears to be more conventional with his/her openness and reveals enjoyment in familiarity (Robbins \& Judge, 2011). Neuroticism concerns the individual's ability to tolerate the stress and perform stability of positive emotion, which is indicated by calm, security, and passion (Robbins \& Judge, 2011). Extroversion concerns pleasure at the individual level in communicating with another. High extroversion people are inclined to be recognized as open and friendly. Meanwhile, introverts are not fully open, and feel happier if they find themselves in solitude. Agreeableness concerns the 
individual's inclination to view submission to the other as the right behavior. People with high agreeableness believe in other people, are cooperative, and easy to please.

Personality traits of Big-Five act as a great role in deciding individuals' behaviors and the habits that are free from external pressure. The personality traits of Big-Five tend to shape the feeling, behaving, and thinking in particular circumstances, and OCB is likewise conducted without any restriction. Hence, the personality traits of Big-Five and $\mathrm{OCB}$ are significantly related (Podsakoff, MacKenzie, Paine, \& Bachrach, 2000). Potentially, the personality traits of BigFive could bring OCB in the working environment together by means of some processes of interconnected. Personality differences would influence how the employee is personally motivated, and also would influence how employee comprehends interpersonal circumstances. An employee who is emotionally stable would be inclined to offer help to another employee in their work completion (Najari et al., 2011).

Several researchers' findings (Ahmadi, 2010; Kumar, Bakhshi, \& Rani, 2009; Leephaijaroen, 2016; Najari et al., 2011; Podsakoff et al., 2000; Singh \& Singh, 2009) have recognized that personality traits of Big-Five impact OCB. Mahdiuon, Ghahramani, and Sharif (2010) reveal prospective variables of some personality traits of the Big-Five in predicting employees' organizational citizenship behavior, comprising of conscientiousness, openness to experience, and agreeableness. Moreover, Malik, Ghafoor, and Iqba (2012) and Sjahruddin, Armanu, Sudiro, and Normijati (2013) noted that personality traits of Big-Five influence significantly positive on organizational citizenship behavior. Thus,

\section{H4: Personality traits of Big-Five relate positively to $O C B$.}

The personality traits of Big-Five have an essential role in increasing organizational performance effectiveness and efficiency. The effectiveness of the organization would improve strongly when it is reinforced and matched with the employees' mental and personal characteristics (Askarian \& Eslami, 2013). Different personalities form how the employee responds to the occurring circumstance in their working environment (Hooper-Boyd, 2012). An employee who enjoys his/her jobs would show completing assigned tasks better (Chu, Lee, \& Chao, 2012).

Some studies also reveal that personality traits of BigFive have a significant effect on commitment of organization (Abdullah, Omar, \& Rashid, 2013), employee well-being (Marzuki, 2013), and employee performance (Askarian \& Eslami, 2013; Bhatti, Battour, Ismail, \& Sundram, 2014; Chu et al., 2012; Harris \& Fleming, 2017; Hooper-Boyd, 2012). Hence,

H5: Personality traits of Big-Five relate positively to the performance of task.

\section{Research Methodology}

\subsection{Sample and Data Collection}

The population surveyed was civilians who work in the electricity sector in South Sulawesi cities of Kolaka, Kendari, Wakatobi, and Bau-Bau. The sampling technique was completed through simple random sampling. There were 350 questionnaires distributed. Incomplete responses were eliminated, which resulted in 246 valid questionnaires $(70.2 \%)$ for further analysis. From 246 respondents, $45 \%$ were female and $55 \%$ were male. Also, the age of the majority of respondents is $31-40$ years $(39.43 \%)$ and $41-50$ years $(33.33 \%)$, the work experience exceeded seven years for $47.38 \%$ of respondents and above seven years for $52.84 \%$, in the same job. Respondents' educational level was mostly university graduates $(82.52 \%)$ and the remaining $(17.48 \%)$ only attended senior high school (see Table 1).

\subsection{Measurement}

There are 18 items contained in the questionnaire and those items were tested through a 5-point Likert scale: 1 is 'strongly disagree', 5 is 'strongly agree'. Four dimensions were proposed to measure the psychological capital - hope, self-efficacy, optimism, and resilience (Bandura, 1997). Experience, extraversion, conscientiousness, neuroticism, and agreeableness, as part of Big-Five personality traits, were calculated from scale 1-to-4 as adopted from HPI or Hogan Personality Inventory (Hogan, Hogan, \& Murtha, 1992). According to Podsakoff, Ahearne, and Mackenzie (1997), organizational citizenship behavior or OCB was estimated to include civic virtue, conscientiousness, altruism, sportsmanship, and courtesy. Working safely, inspecting, detecting and testing problems using equipment, planning and organizing work, and performing routine maintenance are items used to measure task performance as adapted from Campbell (1987).

\subsection{Structural Equation Modeling and Partial Least Squares}

As part of multivariate analysis technique, structural equation modeling (SEM) tests theoretical models put forward by the researcher. Kline (1998) states that it employs the fusion of statistical data and qualitative causal assumption. The technique is emphasized more compared to exploration, also it is more appropriate to conduct testing rather than mere development of theory. There are two components as the results of SEM, those are the structural model and the measurement model. The structural model 
Table 1: Designation of the Respondents

\begin{tabular}{|l|l|c|c|}
\hline Items & Description & Frequency & Percentage \\
\hline Gender & Male & 135 & 54.88 \\
& Female & 111 & 45.12 \\
\hline Age & $<21$ years old & 6 & 2.44 \\
& $21-30$ years old & 28 & 11.38 \\
& $31-40$ years old & 97 & 39.43 \\
& $41-50$ years old & 82 & 33.33 \\
& $>51$ years old & 33 & 13.42 \\
\hline Education level & University graduates & 203 & 82.52 \\
& Senior high school & 43 & 17.48 \\
\hline Work experience & $1-3$ years & 36 & 14.63 \\
& $4-6$ years & 91 & 36.99 \\
& $>7$ years & 119 & 47.38 \\
\hline Years on the same job & $1-3$ years & 35 & 14.23 \\
& $4-6$ years & 81 & 32.93 \\
& $>7$ years & 130 & 52.84 \\
\hline
\end{tabular}

brings robustness and orientation of latent variables' relationship. Meanwhile, the measurement model allows association of observed variables and latent variables to deliver reliability and validity. Thus, the combination of structural model and measurement model is important to establish the research's quality (Trochim \& Donnelly, 2008).

There are two approaches in SEM: (1) a variance based approach regarding Partial Least Square (PLS); and (2) a covariance-based approach regarding certain tools such as Analysis of Moment Structures (AMOS) and EQS. PLS approach was chosen in this research to conduct data analysis based on the following reasons: requirements relationships research is quite original, and given this situation, there is no available measurement model to date; PLS can be an alternative technique to encounter new phenomena (Chin, 1998).

\section{Results}

In line with Hair, Black, Babin and Anderson's finding (2010), the results of the measurement model show that overall the factor loadings, which have been standardized in every construct, were relatively high $(>0.50)$ to secure the convergent validity. The combined Cronbach's Alpha $\alpha$ and reliability value for whole constructs (4) is $>0.70$, which secures internal consistency and this is in accordance with the research by (Hair, Black, Babin, \& Anderson, 2010). Next, average variance extracted value or AVE of four constructs surpasses standard by 0.50 and was greater than the squared correlations between all set of constructs in this study (see Table 2). Considering the reliability and validity's figures and measurements, hence, these circumstances are qualified for further hypotheses testing and structural models.

Table 3 shows the findings of the SmartPLS M3 Version 2.0 software proposed by Ringle, Wende, and Will (2005), also it was administered to examine hypotheses H1 to H5.

The findings reveal: (1) OCB was not notably associated with task performance $(t$-statistic $=0.288, \beta=0.008) ;(2)$ psychological capital was remarkably connected to OCB $(t$-statistic $=3.051, \beta=0.091)$, and task performance $(t$-statistic $=52,328, \beta=0.759)$; and (3) personality traits were connected to OCB $(t$-statistic $=14.348, \beta=0.424)$, and task performance $(t$-statistic $=6,249, \beta=0.110)$. Findings concluded that $\mathrm{H} 2, \mathrm{H} 3, \mathrm{H} 4$, and $\mathrm{H} 5$ were accepted, except hypotheses $\mathrm{H} 1$. 
Table 2: Results of Measurement Model

\begin{tabular}{|c|c|c|c|c|}
\hline Construct indicators & Factor loadings & Cronbach $\alpha$ & $\begin{array}{c}\text { Composite } \\
\text { reliability }\end{array}$ & AVE \\
\hline Task Performance & & 0.787 & 0.853 & 0.596 \\
\hline 1. TP1 & 0.856 & & & \\
\hline 2. TP2 & 0.687 & & & \\
\hline 3. TP3 & 0.664 & & & \\
\hline 4. TP4 & 0.858 & & & \\
\hline OCB & & 0.953 & 0.966 & 0.854 \\
\hline 1. OCB1 & 0.696 & & & \\
\hline 2. OCB2 & 0.979 & & & \\
\hline 3. OCB3 & 0.982 & & & \\
\hline 4. OCB4 & 0.957 & & & \\
\hline 5. OCB5 & 0.973 & & & \\
\hline Personality Traits & & 0.864 & 0.900 & 0.644 \\
\hline 1. PT1 & 0.785 & & & \\
\hline 2. РT2 & 0.826 & & & \\
\hline 3. РT3 & 0.789 & & & \\
\hline 4. PT4 & 0.785 & & & \\
\hline 5. PT5 & 0.826 & & & \\
\hline Psychological Capital & & 0.628 & 0.772 & 0.568 \\
\hline 1. PC1 & 0.770 & & & \\
\hline 2. PC2 & 0.511 & & & \\
\hline 3. $\mathrm{PC} 3$ & 0.571 & & & \\
\hline 4. PC4 & 0.832 & & & \\
\hline
\end{tabular}

Table 3: Summary of Hypotheses Testing Results

\begin{tabular}{|l|c|c|c|c|}
\hline & $\boldsymbol{\beta}$ & S.E & T-value & Results \\
\hline OCB $\rightarrow$ Task Performance & 0.008 & 0.028 & 0.288 & Not supported \\
\hline Psychological Capital $\rightarrow$ OCB & $0.091^{* * *}$ & 0.029 & $3.051^{* * *}$ & Supported \\
\hline Psychological Capital $\rightarrow$ Task Performance & $0.759^{* * *}$ & 0.015 & $52.328^{* * *}$ & Supported \\
\hline Personality Traits $\rightarrow$ OCB & $0.424^{* * *}$ & 0.029 & $14.348^{* * *}$ & Supported \\
\hline Personality Traits $\rightarrow$ Task Performance & $0.110^{* * *}$ & 0.018 & $6.249^{* * *}$ & Supported \\
\hline
\end{tabular}




\section{Discussion}

In an aggressive and uncertain business environment, belongingness between employees should be encouraged and strengthened by managers to be successful. At the moment, employees understand that they have become fixtures of certain corporation, they will perceive that their efforts are more significant, in effect, it will boost their performance. Also, managers got to integrate communication in an efficient and effective manner to foster OCB by, for instance, supporting open policies that emancipate workers to be actively involved in the process of making decision.

Murthy (2014) affirmed that the intention of psychological capital investment of employees is to establish adequate competency for employees to prepare themselves to the globalization challenges and enhance organizational citizenship in order to lead to organizational effectiveness. Workers with a stable and positive psychological state will reveal greater OCB than employees with a negative state. The employees' actions and minds will be utilized to their potential by managing the available time. Employees will show skills to present proactive behaviors, namely, making suggestions for improvement or sharing creative ideas (Avey et al., 2008). The findings of this research are in line with previour research that shows a significant positive effect of psychological capital on OCB. Employees with positive psychological capital will perform task simultaneously to shape a positive and unique life in the work environment (Norman et al., 2010). Moreover, employees will struggle to accomplish success by carrying out orders in a better manner. Based on the significant positive effect of psychological capital on employee performance, this study supports the results of previous studies.

Personality also has to deal with determining employee behavior, in acting freely based on orders (Najari et al., 2011). The tendency to think, act, and feel are reflected in personality. Personality differences will affect the reaction of employees to particular situations happening in their work environment (Hooper-Boyd, 2012). Workers with stable feelings will allow other employees to receive assistance in carrying out their tasks. The findings of this research fortifies findings that there is a significant positive effect of Big-Five personality traits on OCB. Personality traits of Big-Five bring significant contribution in enhancing the organizational performance's efficiency and effectiveness (Askarian \& Eslami, 2013). Organizational effectiveness will rise when assisted and congruent with the individual characteristics and mental of employees. Better performance will be exhibited by employees who are fond of their jobs (Chu et al., 2012). These results validate the existence of a significant positive effect of Big-Five personality traits on employee performance.

\section{Conclusion}

The results of this research show that personality traits of Big-Five and psychological empowerment have significant role in supporting employee performance and the behavior of organizational citizenship in the electricity sector in Indonesia, specifically in four major cities (Kendari, Bau-Bau, Kolaka and Wakatobi city). This study adds more empirical evidence concerning the connection between the aforementioned variables.

This research has limitations. Firstly, this research only studies the outcome of personality traits of Big-Five and psychological capital and performance on OCB, thus, further research should integrate other factors contributing to organizational effectiveness. Secondly, further research should enlarge the study's scope, for instance, (1) documenting the presumed connection in other industries and countries, (2) including other groups that might potentially exhibit OCB, namely, police, soldiers, salespeople, and other staff in the service sector, and (3) recruiting lecturers at public and private universities where the findings might be beneficial to create and develop guidelines for OCB and employee performance improvement in other sectors.

In terms of practical implication, the findings of this research posit that psychological capital and Big-Five personality traits aiming to improve employee performance can be most effective if specifically targeted at OCB. Given that both variables play an important role in promoting $\mathrm{OCB}$, caring training initiatives that focus on mutual help can be very valuable for organizational improvement. In a managerial perspective, organizations can increase OCB by conducting open communication strategies between managers and employees to further stimulate and strengthen the ability of employees to display extra-role behaviors.

\section{References}

Abdullah, I., Omar, R., \& Rashid, Y. (2013). Effect of Personality on Organizational Commitment and Employees' Performance: Empirical Evidence from Banking Sector of Pakistan. MiddleEast Journal of Scientific Research, 18(6), 759-766.

Ahmadi, F. (2010). Survey relationship between OCB and internal \& external factors impact on OCB. European Journal of Social Sciences, 16(3), 469-486.

Ashkanasy, N. M., Troth, A. C., Lawrence, S. A., \& Jordan, P. J. (2017). Emotions and Emotional Regulation in HRM: A Multi-Level Perspective. Research in Personnel and Human Resources Management, 35, 1-52.

Asiedu, M., Sarfo, J. O., \& Adjei, D. (2014). Organisational Commitment and Citizenship Behaviour: Tools to Improve Employee Performance, An Internal Marketing Approach. European Scientific Journal, 10(4), 288-305. 
Askarian, N., \& Eslami, H. (2013). The Relationship Between Personality Traits and Job Performance (Case Study: Employees of the Ministry of Education of Kerman). Interdisciplinary Journal of Contemporary Research in Business, 5(8), 322-335.

Avey, J. B., Luthans, F., \& Youssef, C. M. (2008). The Additive Value of Positive Psychological Capital in Predicting Work Attitudes and Behaviors. Journal of Management, 36(2), 1-42. https://doi.org/10.1177/0149206308329961

Bakker, A. B., Albrecht, S., \& Leiter, M. P. (2011). Work engagement: Further reflections on the state of play. European Journal of Work and Organizational Psychology, 20, 74-88.

Bandura, A. (1997). Self-efficacy: Toward a unifying theory of behavioral change. Psychological Review, 84(2), 191-215.

Beal, I., Stavros, J., \& Cole, M. (2013). Effect of psychological capital and resistance to change on organizational citizenship behavior. SA Journal of Industrial Psychology, 39(2), 1-11.

Beheshtifar, M., \& Hesani, G. (2012). Organizational citizenship behavior: A factor to decrease organizational conflict. Interdisciplinary Journal of Contemporary Research in Business, 5(1), 214-222.

Bhatti, M. A., Battour, M. M., Ismail, A. R., \& Sundram, V. P. (2014). Effects of personality traits (big five) on expatriates adjustment and job performance. Equality, Diversity and Inclusion: An International Journal, 33(1), 73-96.

Borman, W. C., \& Motowidlo, S. J. (1993). Expanding the criterion domain to include elements of contextual performance. In: N. Schmitt, W. C. Borman, \& Associates (Eds.), Personnel Selection in Organizations (pp. 71-98). San Francisco, CA: Jossey-Bass.

Buchko, A. A., Buscher, C., \& Buchko, K. J. (2017). Why do good employees stay in bad organizations? Business Horizons, 60(5), 729-739.

Campbell, J. P. (1987). Improving the selection, classification, and utilization of Army enlisted personnel: Annual report, 1985 fiscal year. ARI Technical Report 746. Arlington, VA: Army Research Institute for the Behavioral and Social Sciences.

Carver, C. S., \& Scheier, M. (2003). Optimism. In: S. J. Lopez, \& Snyder, C. R. (Eds.), Positive Psychological Assessment: A Handbook of Models and Measures. Washington, DC: American Psychological Association.

Cervone, D., \& Pervin, L. (2013). Personality: Theory and Research. New York, NY: Wiley and Sons.

Chien, M. H. (2003). A study to improve organizational citizenship behaviors. In: International Congress on Modelling and Simulation (MODSIM03) (pp. 1364-1367). Townsville, Australia. 14-17 July 2003. https://www.mssanz.org.au/ MODSIM03/MODSIM03.htm

Chin, W. W. (1998). The partial least squares approach for structural equation modeling. In: G. A. Marcoulides (Ed.), Modern methods for business research. London, UK: Lawrence Erlbaum Associates.
Chu, P.-Y., Lee, G.-Y., \& Chao, Y. (2012). Service Quality, Customer Satisfaction, Customer Trust, and Loyalty in an E-Banking Context. Social Behavior and Personality, 40(8), 1271-1284.

Coutu, D. L. (2002). How resilience works. Harvard Business Review, 80, 46-55.

Darsana, M. (2013). The Influence of Personality and Organizational Culture on Employee Performances Through Organizational Citizenship Behavior. The International Journal of Management, 2(4), 35-42.

Desivilya, H., Sabag, Y., \& Ashton, E. (2006). Prosocial tendencies in organizations: the role of attachment styles and organizational justice in shaping organizational citizenship behavior. International Journal of Organizational Analysis, 14, $22-42$.

Dong, L. N. T., \& Phuong, N. N. D. (2018). Organizational Justice, Job Satisfaction and Organizational Citizenship Behavior in Higher Education Institutions: A Research Proposition in Vietnam. Journal of Asian Finance, Economics and Business, 5(3), 113-119. http://doi.org/10.13106/jafeb.2018.vol5.no3.113

Hair, J. F., Black, W. C., Babin, B. J., \& Anderson, R. E. (2010). Multivariate data analysis (7th ed.). Englewood Cliffs, NJ: Prentice Hall.

Han, J. H. (2020). The Effects of Personality Traits on Subjective Well-being and Behavioral Intention Associated with Serious Leisure Experiences. Journal of Asian Finance, Economics and Business, 7(5), 167-176. https://doi.org/10.13106/jafeb.2020. vol7.no5.167

Harris, E. G., \& Fleming, D. E. (2017). The productive service employee: personality, stress, satisfaction and performance. Journal of Services Marketing, 31(6), 499-511.

Harwiki, W. (2013). The Influence of Servant Leadership on Organization Culture, Organizational Commitment, Organizational Citizenship Behavior and Employees' Performance (Study of Outstanding Cooperatives in East Java Province, Indonesia). Journal of Economics and Behavioral Studies, 5(12), 876-885.

Herbert, M. (2011). An exploration of the relationship between psychological capital, occupational stress, burnout and employee engagement. Unpublished Thesis. Stellenbosch, South Africa: University of Stellenbosch.

Hmieleski, K. M., \& Carr, J. C. (2008). The Relationship Between Entrepreneur Psychological Capital and New Venture Performance. Frontiers of Entrepreneurship Research, 28(4), $1-15$.

Hodges, T. D. (2010). An Experimental Study of the Impact of Psychological Capital on Performance, Engagement, and the Contagion Effect. Doctorate Dissertation. Lincoln, NE: University of Nebraska.

Hogan, J., Hogan, R., \& Murtha, T. (1992). Validation of a personality measure of managerial performance. Journal of Business and Psychology, 7(2), 225-237. 
Hooper-Boyd, C. L. (2012). Introducing leadership into the mix: An investigation of the relationship between personality characteristics and small business success. Doctorate Dissertation. Minneapolis, MN: Capella University.

Jalal, R. N.-U.-D., Zeb, N., \& Fayyaz, U.-E.-R. (2019). The effect of personality traits on employee job satisfaction with moderating role of Islamic work ethics. Journal of Asian Finance, Economics and Business, 6(2), 161-171. doi: https:// doi.org/10.13106/jafeb.2019.vol6.no2.161

Kang, M., \& Sung, M. (2017). How symmetrical employee communication leads to employee engagement and positive employee communication behaviors: The mediation of employee-organization relationships. Journal of Communication Management, 21(1), 82-102.

Karatepe, O. M., \& Talebzadeh, N. (2016). An empirical investigation of psychological capital among flight attendants. Journal of Air Transport Management, 55, 193-202.

Kim, T. T., Karatepe, O. M., Lee, G., Lee, S., Hur, K., \& Xijing, C. (2017). Does hotel employees' quality of work life mediate the effect of psychological capital on job outcomes? International Journal of Contemporary Hospitality Management, 29(6), 1638-1657.

Kumar, K., Bakhshi, A., \& Rani, E. (2009). Linking the 'big five' personality domains to organizational citizenship behavior. International Journal of Psychological Studies, 1(2), 73-81.

Leephaijaroen, S. (2016). Effects of the big-five personality traits and organizational commitments on organizational citizenship behavior of support staff at Ubon Ratchathani Rajabhat University, Thailand. Kasetsart Journal of Social Sciences, $37(2), 104-111$.

Liu, L., Hu, S., Wang, L., Sui, G., \& Ma, L. (2013). Positive resources for combating depressive symptoms among Chinese male correctional officers: perceived organizational support and psychological capital. BMC Psychiatry, 13, Article number: 89(2013). https://doi.org/10.1186/1471-244X-13-89

Luthans, F., Avey, J., \& Jensen, S. (2009). A Positive Resource for Combating Employee Stress and Turnover. Human Resource Management, 48(5), 677-693.

Luthans, F., Avey, J. B., Avolio, B. J., \& Peterson, S. J. (2010). The Development and Resulting Performance Impact of Positive Psychological Capital. Human Resource Development Quarterly, 21(1), 4-67.

Luthans, F., Avolio, B. J., Avey, J. B., \& Norman, S. M. (2007). Positive Psychological Capital: Measurement and Relationship with Performance and Satisfaction. Personnel Psychology, 60, 541-572.

Luthans, F., Avolio, B. J., Walumbwa, F., \& Li, W. (2005). The psychological capital of Chinese workers: Exploring the relationship with performance. Management and Organisational Review, 1, 247-269.

Luthans, F., \& Jensen, S. M. (2002). Hope: A new positive strength for human resource development. Human Resource Development Review, 1, 304-322.
Maharani, V., Troena, E. A., \& Noermijati. (2013). Organizational Citizenship Behavior Role In Mediating The Effect Of Transformational Leadership, Job Satisfaction On Employee Perfomance Studi In PT. Bank Syariah Mandiri Malang East Java. International Journal of Business and Management, $8(17), 1-12$.

Mahdiuon, R., Ghahramani, M., \& Sharif, A. R. (2010). Explanation of organizational citizenship behavior with personality. Procedia Social and Behavioral Sciences, 5, 178-184.

Malik, M. E., Ghafoor, M. M., \& Iqba, H. K. (2012). Leadership and personality traits as determinants of organizational citizenship behavior (OCB) in banking sector of Pakistan. World Applied Sciences Journal, 20(8), 1152-1158.

Marzuki, N. A. (2013). The impact of personality on employee well-being. European Scientific Journal, 9(20), 43-52.

Masten, A. S. (2001). Ordinary magic: Resilience processes in development. American Psychologist, 56, 227-239.

Murthy, R. K. (2014). Psychological Capital, Work Engagement and Organizational Citizenship Behaviour. Pune, India: Sinhgad Institute of Management and Computer Application (SIMCA).

Najari, R., Ahmadi, F., \& Habibitabar, Z. (2011). Study of Relationship Between Personality and Organizational Citizenship Behavior (OCB) in Public Organizations in Iran. Interdisciplinary Journal of Contemporary Research in Business, 3(2), 472-483.

Nelson, D. L., \& Cooper, C. L. E. (2007). Positive Organizational Behavior. London, UK: Sage Publications.

Nguyen, H. M., \& Ngo, T. T. (2020). Psychological Capital, Organizational Commitment and Job Performance: A Case in Vietnam. Journal of Asian Finance, Economics and Business, 7(5), 269-278. doi: https://doi.org/10.13106/jafeb.2020.vol7. no5.269

Norman, S. M., Avey, J. B., Nimnicht, J. L., \& Pigeon, N. G. (2010). The Interactive Effects of Psychological Capital and Organizational Identity on Employee Organizational Citizenship and Deviance Behaviors. Journal of Leadership \& Organizational Studies, 17(4), 380-391.

Organ, D. W. (1988). Organizational citizenship behavior: The good soldier syndrome. Lexington, MA: D.C. Heath and Company.

Organ, D. W., Podsakoff, P. M., \& MacKenzie, S. B. (2006). Organizational citizenship behavior: Its nature, antecedents, and consequences. Thousand Oaks, CA: Sage Publications.

Peterson, S. J., Luthans, F., Avolio, B. J., Walumbwa, F. O., \& Zhang, Z. (2011). Psychological capital and employee performance: a latent growth modeling approach. Personnel Psychology, 64, 427-450.

Podsakoff, P. M., MacKenzie, S. B., Paine, J. B., \& Bachrach, D. G. (2000). Organizational citizenship behaviors: A critical review of the theoretical and empirical literature and suggestions for future research. Journal of Management, 26(3), 513-563. 
Poulsen, S., \& Ipsen, C. (2017). In times of change: How distance managers can ensure employees' wellbeing and organizational performance. Safety Science, 100(Part A), 37-45.

Pradhan, R. K., Jena, L. K., \& Bhattacharya, P. (2016). Impact of psychological capital on organizational citizenship behavior: Moderating role of emotional intelligence. Cogent Business \& Management, 3, 1-16.

Putri, E. R., Udin, \& Djastuti, I. (2019). Structural empowerment and service-oriented organizational citizenship behavior: The mediating roles of innovativeness and job satisfaction. QualityAccess to Success, 20(170), 112-117.

Rashi, M. J. C., \& Konark, J. N. (2002). Job satisfaction and organizational citizenship behaviour: A study of Indian humanservice professionals. Journal of Managerial psychology, 4, 287-297.

Rayner, J., Lawton, A., \& Williams, H. M. (2012). Organizational citizenship behavior and the public service ethos: Whither the organization? Journal of Business Ethics, 106(2), 117-130.

Rego, A., Marques, C., Leal, S., Sousa, F., \& Cunha, M. (2010). Psychological Capital and Performance of Portuguese Civil Servants: Exploring Neutralizers in the Context of an Appraisal System. The International Journal Of Human Resource Management, 21(9), 1531-1552.

Ringle, C. M., Wende, S., \& Will, A. (2005). SmartPLS 2.0. Hamburg, Germany: SmartPLS. www.smartpls.de.

Robbins, S. P., \& Judge, T. (2011). Organizational Behavior (14th ed.). Englewood Cliffs, NJ: Prentice Hall.

Shahab, M. A., Sobari, A., \& Udin, U. (2018). Empowering Leadership and Organizational Citizenship Behavior: The Mediating Roles of Psychological Empowerment and Emotional Intelligence in Medical Service Industry. European Research Studies Journal, 21(Special Issue 3), 403-412.

Singh, A. K., \& Singh, A. P. (2009). Does personality predict organizational citizenship behavior among managerial personnel. Journal of the Indian Academy of Applied Psychology, 35(2), 291-298.
Sjahruddin, H., Armanu, Sudiro, A., \& Normijati. (2013). Personality effect on organizational citizenship behavior (OCB): Trust in manager and organizational commitment mediator of organizational justice in Makassar City Hospital (Indonesia). European Journal of Business and Management, 5(9), 95-104.

Snyder, C. R., Sympson, S. C., \& Ybasco, F. C. (1996). Development and validation of the State Hope Scale. Journal of Personality \& Social Psychology, 70(2), 321-335.

Suwanti, S., \& Udin, U. (2020). Investigating the Relationship between Person-Organization Fit, Person-Job Fit, and Innovative Work Behavior: The Mediation Role of Organizational Citizenship Behavior. Quality-Access to Success, 21(176). [Indonesian]

Trochim, W. K. T., \& Donnelly, J. P. (2008). The research methods knowledge base (3rd ed.). Mason, $\mathrm{OH}$ : Atomic Dogg CENGAGE Learning.

Tüzün, I. K., Çetin, F., \& Basim, H. N. (2018). Improving job performance through identification and psychological capital. International Journal of Productivity and Performance Management, 67(1), 155-170.

Venkatesh, R., \& Blaskovich, J. (2012). The Mediating Effect of Psychological Capital on the Budget Participation-Job Performance Relationship. Journal of Management Accounting Research, 24, 159-175.

Ward, M. K., Meade, A. W., Allred, C. M., Pappalardo, G., \& Stoughton, J. W. (2017). Careless response and attrition as sources of bias in online survey assessments of personality traits and performance. Computers in Human Behavior, 76, 417-430.

Yardley, K. (2012). Psycholigical capital As A Positive Resource to asisist With the organizational outcomes of woek family conflict. Master Thesis. Auckland (Albany), New Zealand: Massey University.

Youssef, C. M., \& Luthans, F. (2010). An integrated model of psychological capital in the workplace, in Linley PA, Harrington S and Garcea N (Eds.) Oxford handbook of positive psychology and work. New York, NY: Oxford University Press. 